\title{
Material and Energy Recovery from the Final Disposal of Organic Waste
}

\author{
Gabriele Di Giacomo
}

Citation: Di Giacomo, G. Material and Energy Recovery from the Final Disposal of Organic Waste. Energies 2021, 14, 8459. https://doi.org/ 10.3390/en14248459

Received: 8 December 2021 Accepted: 13 December 2021 Published: 15 December 2021

Publisher's Note: MDPI stays neutral with regard to jurisdictional claims in published maps and institutional affiliations.

Copyright: (C) 2021 by the author. Licensee MDPI, Basel, Switzerland. This article is an open access article distributed under the terms and conditions of the Creative Commons Attribution (CC BY) license (https:// creativecommons.org/licenses/by/ $4.0 /)$.
Department of Industrial and Information Engineering and of Economics, Campus of Roio, University of L'Aquila, 67100 L'Aquila, Italy; gabriele.digiacomo@univaq.it

While receiving nearly 10,000 times the energy that we presently need from the Sun, almost $600 \mathrm{EJ} / \mathrm{a}$, developed and developing countries continue to mostly use fossil fuels even though the technologies available and the adaptation of individual and collective behaviours could make it possible to use only solar energy.

For example: in developed countries, the drinking water consumption has exceeded $0.2 \mathrm{~m}^{3}$ per capita per day, even in arid areas where it is produced using a large amount of fossil-based energy; the consumption of fossil-derived fuels for automotive industries reached a level that was unimaginable until a few decades ago; food is produced and marketed, throwing half of the raw material. Additionally, it is absurdly packaged and consumed for a share that does not exceed 50\% after keeping in the refrigerator, without any concern for the energy consumption.

All this and much more are part of a long list of irrational and unnatural behaviours and habits.

Each year, the solar energy accumulated as biomass is eight times greater than the current global energy consumption. Still, few appreciate this gift that nature continues to give us. Most of this precious and energy-intensive material is just discharged into the environment or landfilled as waste, thus losing its GHG emission neutral energetic content and the possibility of its mining for producing a variety of precious and renewable compounds.

Waste-to-energy can potentially contribute about $5 \%$ to energetic global consumption, and this is not such an enormous contribution; it would be better to avoid or reduce the production of waste drastically. However, some constraints, such as urbanization, make this impossible. Furthermore, the irreversible habits typical of modern living does not allow this. However, we have a moral duty to use the best technologies and strategies to value biomass waste.

We suggested that this Special Issue should meet this moral duty and received ten exciting contributions.

1. The Effective Management of Organic Waste Policy in Albania [1].

2. Anaerobic Degradation of Environmentally Hazardous Aquatic Plant Pistia stratiotes and Soluble $\mathrm{Cu}(\mathrm{II})$ Detoxification by Methanogenic Granular Microbial Preparation [2].

3. Influence of Valorization of Sewage Sludge on Energy Consumption in the Drying Process [3].

4. Challenges in Sustainable Degradability of Bio-Based and Oxo-Degradable Packaging Materials during Anaerobic Thermophilic Treatment [4].

5. Environmental and Economic Aspects of Biomethane Production from Organic Waste in Russia [5].

6. Adsorptive Recovery of Cd(II) Ions with the Use of Post-Production Waste Generated in the Brewing Industry [6].

7. Modern Use of Water Produced by Purification of Municipal Wastewater: A Case Study [7]. 
8. Odour Nuisance at Municipal Waste Biogas Plants and the Effect of Feedstock Modification on the Circular Economy-A Review [8].

9. Operational Parameters of Biogas Plants: A Review and Evaluation Study [9].

10. Pilot-Scale Experiences with Aerobic Treatment and Chemical Processes of Industrial Wastewaters from Electronics and Semiconductor Industry [10].

As can be seen from the titles of the papers, many problems have been addressed, and different technologies were critically evaluated to successfully afford the final disposal and valorization of a variety of waste biomass.

We have worked through the pandemic crisis with incredible difficulty: inaccessible research laboratories, complicated relationships, and very low morale. Nevertheless, we are happy with this work and this example. We extend thanks to all authors from different countries (Romania, Russia, Ukraine, Poland, Germany, Jordan, and Italy) with different degrees of development and problems and aims.

The involvement of many universities, national academies of sciences, and research centers give this Special Issue the unique value that comes from combining different experiences and ways of affording success and solving complex problems.

We hope that everyone will share the desire to name this Special Issue of Energies after Ida, a brilliant young colleague. She contributed to this work but failed to overcome a dark evil and gracefully walked away.

Funding: This research received no external funding.

Acknowledgments: I would like to thank MDPI for allowing this work to be published, and the reviewers.

Conflicts of Interest: The author declares no conflict of interest.

\section{References}

1. Oncioiu, I.; Căpuşneanu, S.; Topor, D.; Petrescu, M.; Petrescu, A.; Toader, M. The Effective Management of Organic Waste Policy in Albania. Energies 2020, 13, 4217. [CrossRef]

2. Havryliuk, O.; Hovorukha, V.; Savitsky, O.; Trilis, V.; Kalinichenko, A.; Dołhańczuk-Śródka, A.; Janecki, D.; Tashyrev, O. Anaerobic Degradation of Environmentally Hazardous Aquatic Plant Pistia stratiotes and Soluble $\mathrm{Cu}$ (II) Detoxification by Methanogenic Granular Microbial Preparation. Energies 2021, 14, 3849. [CrossRef]

3. Siedlecka, E.; Siedlecki, J. Influence of Valorization of Sewage Sludge on Energy Consumption in the Drying Process. Energies 2021, 14, 4511. [CrossRef]

4. Zaborowska, M.; Bernat, K.; Pszczółkowski, B.; Wojnowska-Baryła, I.; Kulikowska, D. Challenges in Sustainable Degradability of Bio-Based and Oxo-Degradable Packaging Materials during Anaerobic Thermophilic Treatment. Energies 2021, 14, 4775. [CrossRef]

5. Zueva, S.; Kovalev, A.; Litti, Y.; Ippolito, N.; Innocenzi, V.; De Michelis, I. Environmental and Economic Aspects of Biomethane Production from Organic Waste in Russia. Energies 2021, 14, 5244. [CrossRef]

6. Kalak, T.; Walczak, J.; Ulewicz, M. Adsorptive Recovery of Cd(II) Ions with the Use of Post-Production Waste Generated in the Brewing Industry. Energies 2021, 14, 5543. [CrossRef]

7. Tomassi, G.; Romano, P.; Di Giacomo, G. Modern Use of Water Produced by Purification of Municipal Wastewater: A Case Study. Energies 2021, 14, 7610. [CrossRef]

8. Wiśniewska, M.; Kulig, A.; Lelicińska-Serafin, K. Odour Nuisance at Municipal Waste Biogas Plants and the Effect of Feedstock Modification on the Circular Economy-A Review. Energies 2021, 14, 6470. [CrossRef]

9. Nsair, A.; Onen Cinar, S.; Alassali, A.; Abu Qdais, H.; Kuchta, K. Operational Parameters of Biogas Plants: A Review and Evaluation Study. Energies 2020, 13, 3761. [CrossRef]

10. Innocenzi, V.; Zueva, S.; Vegliò, F.; De Michelis, I. Pilot-Scale Experiences with Aerobic Treatment and Chemical Processes of Industrial Wastewaters from Electronics and Semiconductor Industry. Energies 2021, 14, 5340. [CrossRef] 